\title{
Relevance of Social Studies Curriculum Content for Enhancing Responsibility among Preschool Children in Nairobi County, Kenya
}

\author{
Ganira Khavugwi Lilian \\ Department of Educational Communication and Technology, University of Nairobi, \\ P.O BOX 30197-00100 Nairobi, Kenya \\ Email:kganira@yahoo.com \\ Odundo Amollo Paul (Corresponding author) \\ Department of Educational Communication and Technology, University of Nairobi, \\ P.O BOX 30197-00100 Nairobi, Kenya \\ Email: odundopaul@yahoo.com \\ Gatumu Jane. C \\ Department of Educational Communication and Technology, University of Nairobi, \\ P.O BOX 30197-00100 Nairobi, Kenya \\ Email: jcgatumu@yahoo.com \\ Muasya Juliet Njeri \\ Department of Educational Communication and Technology, University of Nairobi, \\ P.O BOX 30197-00100 Nairobi, Kenya \\ Email: jnerim@yahoo.com
}

Received: June 29, 2018

Accepted: July 16, 2018

Published: August 20, 2018

doi:10.5296/jet.v5i2.13613

URL:http://dx.doi.org/10.5296/jet.v5i2.13613

\begin{abstract}
Relevance of preschool social studies curriculum content develops learners' sense of belonging to the community and country for effective cohesiveness. Sense of belonging is achieved through inculcating right dispositions for reinforcing responsive, efficient and effective individuals in preparation for citizenship in adulthood. Nurturing sense of responsibility among learners creates skilled and informed individuals sensitive to social issues
\end{abstract}


who effectively nurture cohesiveness as participants in a just society. The study was informed by evaluation research model using both quantitative and qualitative interpretative paradigms. The social constructivist theoretical framework informed the study in determining relevance of social studies curriculum content in enhancing the value of responsibility among preschool children in Nairobi County. Evaluating social studies curriculum content was drawn from 'neighborhood, my school and healthy practices' as key determinants of responsible citizens within a community. The target population was 98 preschool teachers purposely sampled from 211 preschools. Questionnaire for preschool teachers were used as the main data collection instrument. Quantitative data was summarized and organized according to research questions and arranged into themes for analysis. The findings indicated that social studies curriculum content is relevant in enhancing responsibility among preschool children. The study recommends that teachers should plan, design class environment and the social studies instruction in ways that cultivate effective civic practice of responsibility.

Keywords: Learner; Social studies; Curriculum; Responsibility; Respect; content; Preschool

\section{Introduction}

Social studies curriculum content is intended to institute ground rules for guiding ethics, rights, duties, obligations and consciousness for preparing learners for citizenship. In support of this position, Copple and Bredekamp (2009) argued that relevance of social studies curriculum content develops learners' sense of consciousness and belonging to the community and country as responsible citizens. In addition, sense of belonging and consciousness may be achieved through inculcating and nurturing responsibility among learners as citizens. According to Carr (2011) responsibility is anchored on being dependable, ability to keep promises and honoring commitments for the good of all. To achieve this, efforts to establish relevance of social studies curriculum content has been encouraged for enhancing value creating education focusing on the extent to which learning results into learner ability to be dependable and keep promises as responsible citizens. In a study on integration of social studies curriculum content Field, Bauml and Ledbetter (2011) indicated that instilling sense of responsibility in learners through accepting consequences for individual actions and conversations should at all times reflect ideals of society. Based on this realization, Shuttleworth and Marri (2014) proposed that social studies curriculum content remain a powerful tool for instilling sense of responsibility among learners in preparation for citizenship in adulthood. However, Young and Lambert (2014) affirmed that as much as social studies curriculum content is values-oriented, learners continue to display disrespect for teachers, aggression and stealing which are against the tenets of responsibility in society. The mismatch between values articulated in social studies curriculum content and practice of responsibility as a duty has been blamed as the source of problems experienced in school and in community. More still, Wayne- Ross, Mathison and Vinson (2013) focusing on relevance of social studies content, suggested that curriculum standardization should stress values such as responsibility for developing efficient and effective citizenship among learners when progressing from child into adulthood. Further, authentic learning experiences which are drawn from concrete encounters assist learner assume personal responsibility for own actions and demonstrate informed and effective citizenship by displaying responsiveness to the 
values of the society supporting growth into adulthood. This position shows that social studies curriculum content is relevant in entrenching societal values among learner from the formative years into adulthood as responsible citizens. To achieve this, the study sought to evaluate social studies curriculum content as an anchor for enhancing values such as responsibility in creating good citizenship among learners in preschools in Nairobi County, Kenya.

Relevance of social studies curriculum content is achieved when learners acquire knowledge, skills, values and commitment as informed and responsible citizens. However, Wayne- Ross, Mathison, and Vinson, (2013) indicated that social studies curriculum in many instances fail to produce responsible citizens which is occasioned by inappropriate implementation approaches during early years of learning. The inappropriate approaches adopted in teaching of social studies curriculum weakens promotion of civic responsibility, widening the gap between learnt content in class and behavior dispositions exhibited in society as growing citizens. In an earlier comment by Mezieobi (2004) while opining that social studies curriculum instruction assists learners to assume roles of responsibility as well as contributors to responsiveness to the values of the society, little has been attained following the adoption of mismatch in methodologies and the intended benefits of good citizenship. Further to this, in instances where learners assume increased roles as responsible citizens, there is likelihood of creating skilled and informed individuals sensitive to social issues who effectively nurture cohesiveness as participants in a just society. More still, in concurrence with Mezieobi (2004) knowledge, skills and values acquired through social studies curriculum assist learner assume personal responsibility for own actions as a pathway to good citizenship during formative years and adulthood. In an effort to establish the relevance of social studies curriculum content, acquisition of knowledge and skills in solving problems and making reasoned decisions as tenets of responsible citizenship were evaluated. In addition, evaluating social studies curriculum content was drawn from 'neighborhood, my school and healthy practices' as key determinants of responsible citizens within a community.

\subsection{Social Studies Curriculum Content, Neighborhood and Responsibility}

Social studies curriculum content is designed to assist learners reach full potential through a programme that inculcates responsibility among learners. Educating learners to take individual accountability for own actions are both school and societal responsibility. Learners may not have a firm grasp of personal responsibility in relation to the surrounding. To realize these, learners may be encouraged during formative years to grasp concept of responsibility to enhance societal cohesiveness. In agreement, Gartrell (2012) affirmed that social studies curriculum content on neighborhood provides first sense of community for learners outside home as these promotes cohesion in the society. Sense of community begins as learners form relationships and participate in decision making in class, which goes beyond the school to the neighborhood. Knowledge on neighborhood is likely to instill competencies that nurture sense of responsibility among learners within the immediate home environment. Drawing from this, knowledge on neighborhood should therefore develop not only an understanding of different people, work activities and recognizing seniors but also instill competencies that lead to sense of responsibility for effective citizenry. This is in concurrence with Colker 
(2012) assertion that connecting learners to other people in the immediate environment enhances sense of belonging, effective decision making, and responsiveness. In instances where teachers instill values inherent in social studies curriculum content on neighborhood effectively, learners are likely to apply concepts learnt from immediate environment in practicing responsiveness for cohesiveness and sustained learning. Against this realization, Crocco and Marino (2014) affirmed that lessons on neighborhood provides learners with opportunities to appreciate and recognize use of resources, identify with good and bad behaviors, discover safe and unsafe places within the vicinity, which in turn develops skills for problem solving. Skills for problem solving would assist learners in establishing foundations of responsibility for settling challenges arising from school and society as productive citizens.

\subsection{Social Studies Curriculum Content, My School and Responsibility}

Educating learners to recognize people in school, activities and care for school property should nurture sense of responsibility for effective citizenship. Learners should acknowledge that being part of the school community involves recognizing people and activities and caring for school property as part of responsibility. This is in tandem with Brown, Crowley and King (2011) assertion that diversity in society requires teachers to deliberately lay a foundation that allow every learner to acquire positive values of which responsibility is central. These dispositions enable learners to develop knowledge, values and attitudes for civic responsibility. In support of these argument, Seefelt, Castle and Falconer (2010) asserted that instilling acts of responsibility, supported with guidance from teachers, assist learners to listen to others, contribute own ideas, and accept decisions that affect the group as a whole. In cases where learners appreciate self and others, uses courteous words and recognize views of others, there are is likelihood of entrenching sense of responsibility in school, and throughout life for effective citizenry. Further, in an effort to establish effectiveness of content knowledge on value creating education, Ganira, and Odundo (2017) indicated that teacher's background knowledge of curriculum implementation and pedagogical practices are critical in developing responsiveness among learners. Based on this assertion, knowledge on roles of people in the school should assist learners grasp the idea that sense of responsibility lays a firm foundation for future roles as informed and dependable citizens.

\subsection{Social Studies Curriculum Content, Health Practices and Responsibility}

The extent to which learners appreciate environment and demonstrate responsibility is dependent on relevance of knowledge and skills on healthy practices. In this regard, Ganira, Odundo and Mwanda, (2015) indicated that integrating health practices in preschool curriculum imparts positively on values that learners require for survival in modern society as responsible citizens. Encouraging acts of hand washing, table etiquette and toileting should at all times instill sense of responsibility among learners. In concurrence, Hansen, Holmes and Lindemann (2013) suggested that empowering learners to recognize acts of health practices is the initial step towards personal responsibility, accountability and restraint from diseases. Drawing from these, schools should not only focus on delivery of cognitive skills, but also instill sense of responsibility for learners to own up on health issues as effective citizens. In 
support of this contention, Kenya institute of curriculum development (KICD 2017) reforms emphasizes integration of values in all curricular from preschool level. Integration of values in school curricular would enable learners to recognize acts of hand washing, table etiquette, and toileting as vital requisite for personal responsibility. In an earlier study on health education, Catherine, Chittleborough, Alexandra, Nichoson and Rona (2012) affirmed that initiating and maintaining appropriate health practices are viewed as social norms that reduce absenteeism in schools. Hence, reducing absenteeism in school is the first step towards nurturing sense responsibility among learners. Further still, Andy (2015) asserted that reinforcing hand washing is critical towards establishing responsibility as a personal value. It is based on this background that the study sought to examine relevance of preschool social studies curriculum content on enhancement of responsibility among learners in Nairobi County, Kenya.

\section{Statement of the Problem}

Relevance of social studies curriculum content is achieved when learners acquire knowledge, skills, values and commitment as informed and responsible citizens. However, Wayne- Ross, Mathison, and Vinson, (2013) indicated that social studies curriculum in many instances fail to produce responsible citizens which is occasioned by inappropriate implementation approaches during early years of learning. The inappropriate approaches adopted in teaching of social studies curriculum weakens promotion of civic responsibility, widening the gap between learnt content in class and behavior dispositions exhibited in society as growing citizens. As much as the KICD (2017) preschool curriculum recognizes that learners need to be critically literate in order to synthesize information and make morally informed decisions as responsible citizens, this has not been fully achieved. Further, despite the fact that social studies curriculum content is values-oriented, learners continue to display disrespect for teachers, aggression and stealing which are against the tenets of responsibility in society. Based on this realization, the study evaluated the extent to which content on neighborhood, my school and health practices enhances the value of responsibility among preschool learners in Nairobi County.

\section{Purpose and Objectives}

The purpose of this study was to determine relevance of social studies curriculum content for enhancing the value of responsibility among preschool children in Nairobi County, Kenya. The specific objectives of the study were to determine how relevant social studies curriculum content on neighborhood, my school and health practices enhances the value of responsibility among preschool children in Nairobi County.

\section{Theoretical Framework}

The study was anchored on social constructivist approach Vygotsky (2005) as its theoretical framework. Social constructivist perspective emphasizes learning through societal interaction and value placed on cultural background of the learner. According to Vygotsky (2005) effective learning depends on learner interaction structured and designed by the teacher. To achieve this, teachers should design the learning environment to nurture and enhance 
thoughtful engagements that help learners develop effective interactions that contribute to problem solving and civic responsibility. In support of this position, Bracken and Fischel, (2007) acknowledged that social constructivist approach emphasizes modern values through active learner participation. Through active learner participation, social constructivist approach provide opportunities for linking learner knowledge and skill taught in class to personal and practical life experiences. Thus, the study considered preschool learners as an essential value in the learning process as posited by Vygotsky (2005), who regarded knowledge acquisition process an interactive communication. Drawing from these, teachers should structure learning activities to support learners develop skills that enhance positive interaction geared towards responsiveness in society. In concurrence, Vygotsky (2005) and supported by Kukk (2010) affirmed that value education is successful when teaching and learning takes place in social situations. In practice social constructivists approach knowledge exchange has gained importance in the social environment. Agreeing with Bracken and Fischel (2007), this study was designed on the basis of social constructivist principles that value education depends on social environment and the ability of teachers to provide learners with competencies that empower demonstration of effective citizenship. In this regard, neighborhood, my school, and health practices were singled out as crucial in enabling preschool learners develop responsibility for cohesiveness in society.

\section{Conceptual Framework}

The conceptual framework was anchored on literature reviewed and study objectives to establish relevance of social studies curriculum content for enhancing responsibility among learners. According to Regoniel (2015) conceptual framework sets the stage for presentation of particular research question that drives the study based on problem statement and variables. Social studies curriculum content on 'neighborhood, my school and healthy practices' were singled out to establish the extent to which preschool learners have acquired responsibility for effective citizenship. Specifically knowledge on; Persons living in the neighborhood; work activities in the environment; recognizing seniors in the community and people in school; activities in school; care for school property; hand washing and table etiquette toileting would nurture development of responsibility among learners as illustrated in figure 1. 


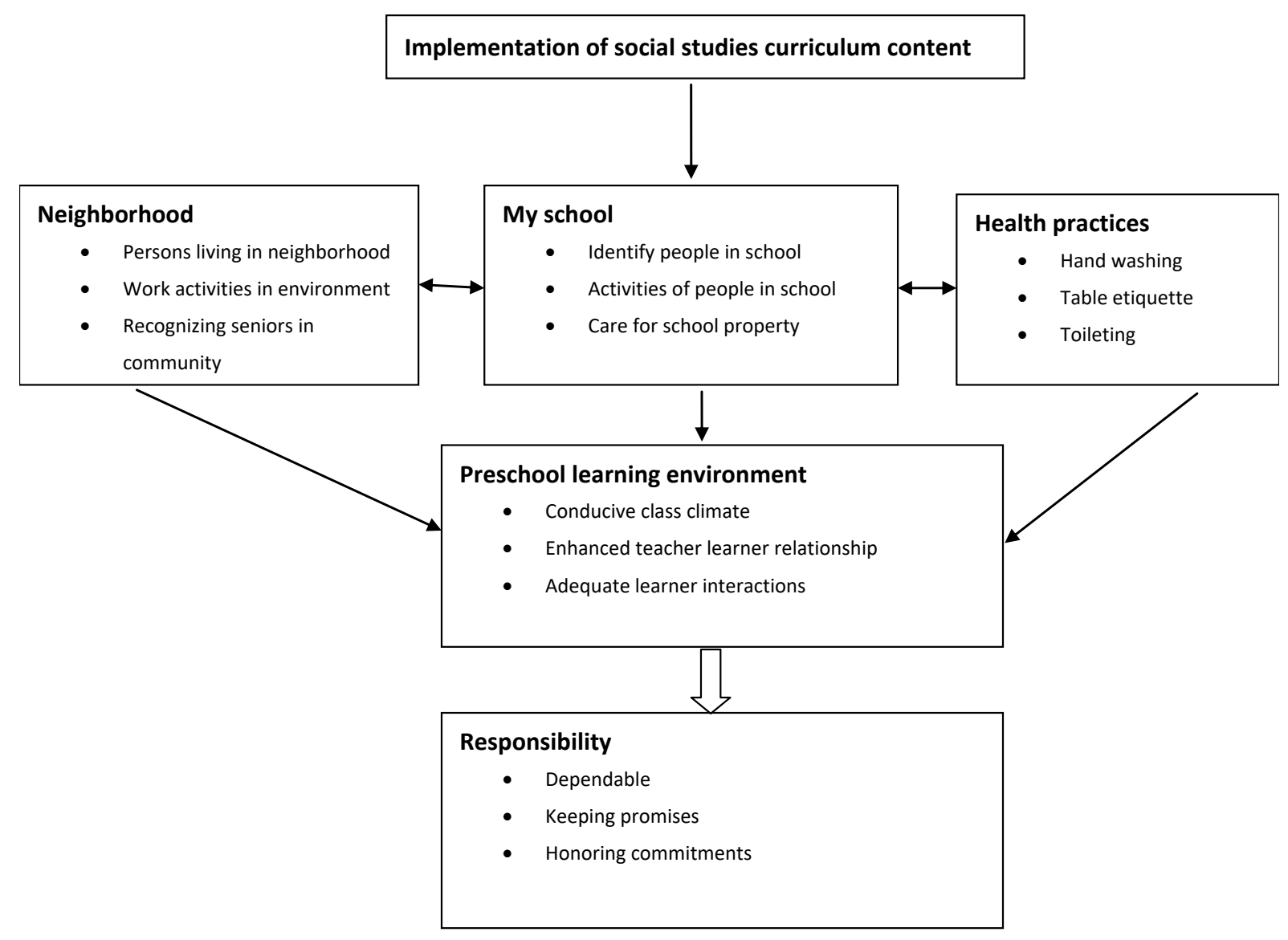

Figure 1. Conceptual framework on relevance of social studies curriculum content and responsibility

\section{Methodology}

The study adopted an evaluation research model based on both quantitative and qualitative interpretative paradigms. Quantitative approach as described by Creswell (2008) is a means for examining the relationship among variables in a study. The variables are measured so that the data generated can be analyzed using statistical procedure. Qualitative approach on the other hand enables understanding and interpretation of situations, events and meaning from people involved. Agreeing with this argument Cohen, Manion, and Morrison, (2011), explained that in qualitative interpretative paradigm words are emphasized when collecting and analyzing data instead of frequencies and distributions. Further, Orodho, Nzabalirwa, Odundo, Ndirangu and Ndayambaje (2016), indicated that choosing methods for data collection means considering available alternatives and continually re-examining and modifying decisions. In this study, quantitatively concepts that influence value of responsibility among preschool children in Nairobi County were examined precisely. At the same time concepts emerging from the data were worked on iteratively between the themes to establish a comprehensive conclusion.

Using stratified random sampling, preschools were selected from each of Nairobi's 11 sub-counties. Stratified random sampling was systematically carried out to ensure each of 
the 11 sub counties were represented on the basis of the percentage number of preschools (Saunders et al, 2009). From the selected schools, preschool teachers were purposely sampled to provide information. Data collection instrument are used in securing information under study from a selected number of respondents (Creswell \& Piano Clark, 2011). Data collection for this study employed the use of questionnaires for preschool teachers. The researcher depended on supervisors and two expert statisticians in verifying the content validity of the questionnaire, interview schedules, observation guide, and documentary analysis guide. In concurrence with Haradhan (2017) improving validity of instruments involves identifying vague questions and deficiencies then make improvements plus providing clarity of instructions. In this study, assistance and suggestions from the supervisors was used to make clarify questions where necessary and slot in new items. In order to establish reliability, the questionnaire was administered to the same pilot sample twice in an interval of two weeks. As noted by Creswell and Piano Clark (2011) the two week interval was appropriate to avoid the impact of repetition and to disuse by respondents.

\section{Study Findings and Discussions}

The study findings were drawn from 98 preschool teachers out of 109 sampled $(89.9 \%)$ which was considered adequate for analysis to establish relevance of social studies curriculum for enhancing responsibility among preschool children. This study sought mainly from preschool teachers in Nairobi County the relevance of social studies curriculum content in enhancing responsibility among children by gathering data through questionnaires.

\subsection{Characteristics of Preschool Teachers}

Preschool teachers were used to provide empirical evidence on relevance of social studies curriculum content in enhancing responsibility among children in Nairobi County. Table 1 presents information on characteristics of preschool teachers in Nairobi County.

\section{a. Preschool Teachers' Ages}

Age is determinant of experience in the implementation of preschool social studies curriculum. From findings presented in Table 4.2 majority of preschool teachers were of ages 40-49 years old while those above 50years were the least. Specifically, 38.5\% (38) were 40-49 years, $35.7 \%$ (35) were 30-39years, $19.4 \%$ (19) were $20-29$ years and $6.01 \%$ (6) were above 50years of age. It took after independence for ECD to be recognized and incorporated in Kenyan education system until 1988. Through a Partnership Policy ECE was first stipulated in the Session Paper No. 6 of 1988 and the National Development Plan of 1989/1993. This is an indication that as career choice for ECE came in 1990s and oldest individuals who were directly trained fall between ages 30-49 years, whom accumulatively were 74.2 (73\%). Small number of those aged above 50years was witnessed because they came out of school before ECE was a critically taken in Kenya.

\section{b. Preschool Teachers' Gender,}

Preschool teachers can be of both genders. However this sought to establish gender distribution of preschool teachers within Nairobi County. The study findings in table 4.2 indicated that cumulatively, out of 98 respondents, 10(10.2\%) were males while the majority 
$88(89.8 \%)$ were females. These findings concur with $\mathrm{Fu}$ and $\mathrm{Li}(2010)$ affirmation that teaching profession is predominantly female. $\mathrm{Fu}$ and $\mathrm{Li}$ (2010) study was carried in Taiwan and the fact that there is concurrence in gender distribution, this study can conclude that preschool teachers are predominantly females. Interestingly, in a study on gender disparity among preschool teachers Ngure (2014) found out that parents preferred female to male to teach values to their children. This shows a cultural stereotype which prefers female teachers over male counterparts in handling preschool children. Further, Nelson and Shikwambi (2010) affirmed that the professionalism of male preschool teachers may be based on children's perceptions that female teachers are caring in the absence of their mothers. The finding that $10.2 \%$ (10) of preschool teachers were males is an indication the labor market has made it possible for male to consider teaching preschool children. This echoes Charlotta (2014) argument that the changing gender patterns among preschool teachers in Sweden has been dictated by the labor market.

\section{c. Preschool Teachers Level of Education}

Teacher education level represents ability to manage class efficiently, demonstrates effective teaching approaches and efficiently utilizes instructional resources to realize set goals. The study sought to examine teachers' educational level and the results as posted in Table 4.2 indicates that $53(54.1 \%)$ had O' level while $45(45.9 \%)$ had reached A' level of education. These findings justify that the level of education for preschool teachers is appropriate for implementation of ECD social studies curriculum. It also agrees with Manning, Garvis, Flaming and Wong (2017) that quality of staff in terms of education level significantly influence teaching of values among preschool children.

\section{d. Preschool Teachers Qualification}

Beyond education level, preschool teachers need to be trained to effectively implement preschool social studies curriculum. Professional training for preschool teachers determines the level of knowledge, skills and competencies for instilling values among children. In Kenya, preschool teachers at trained at certificate, diploma, bachelors degree and post-graduate trainings. According to the findings in Table 4.2, majority of preschool teachers in Nairobi County are diploma trained. Specifically, 64.3\% (63) had diploma in ECE, $16.3 \%$ (16) had certificate in ECE, 15.3\% (15) had bachelor in ECE and 4.1\% (4) had masters in ECE. The bigger number of preschool teachers having diploma in education corresponds with the requirements of ECD bill of 2018. Article 36(1b) states that the minimum qualification for preschool teachers should be diploma in ECE. Secondly the labor market dynamics has made people who had superior grades from high school to be attracted to ECE. Higher grades mean one could train at diploma and bachelor degrees level. This further explains increasing number of bachelor (15.3\%) degree holders teaching preschool level. However, most degree holders could be destined to teach at diploma training centers or getting posted within national and County ECE management structures. This category also includes those with postgraduate qualifications and the challenge is that they may not teach preschool for long. 
Table 1.Preschool Teachers Demographic Information.

\begin{tabular}{llcc}
\hline Variable & Indicators & Frequency & Percentage \\
\hline Gender & Male & 10 & 10.2 \\
Age & Female & 88 & 89.8 \\
& 20-29year & 19 & 19.4 \\
& 30-39years & 35 & 35.7 \\
& 40-49years & 38 & 38.8 \\
Level of Education & 50 years and above & 6 & 6.1 \\
& O'Level & 53 & 54.1 \\
Qualifications & A'Level & 45 & 45.9 \\
& Certificate & 16 & 16.3 \\
& Diploma & 63 & 64.3 \\
Experience & Bachelor degree & 15 & 15.3 \\
& Masters Degree & 4 & 4.1 \\
1-5years & 32 & 32.7 \\
Teaching Social & 6-10years & 18 & 18.4 \\
Studies & 11-15years & 19 & 19.4 \\
& 16-20years & 4 & 4.1 \\
Experience in & Over 20years & 25 & 25.5 \\
Current Station & 1-5years & 61 & 62.2 \\
& 6-10years & 15 & 15.3 \\
& 11-15years & 20 & 20.4 \\
& 16-20years & 2 & 2.0 \\
& 16-20years & 46 & 46.9 \\
& Over 20years & 15 & 15.3 \\
& & 26 & 26.5 \\
& 1-5years & 4 & 7.1 \\
\hline \multirow{5}{*}{ 6xperience in } & & &
\end{tabular}

\subsection{Relevance of Social Studies Curriculum Content on Responsibility}

Being responsible means answering for actions and words, being dependable and trustworthy, and using good judgment. In this regard, teaching responsibility should enable children emerge as informed and dependable citizens. This study considered responsibility to mean being dependable, keeping promises and honoring commitments (Carr, 2011). Further, Odundo, and Ganira (2017) commenting on teacher position in spurring value based education in early learning indicated that schools should provide opportunities for learners to exhibit harmonious social interactions for acting responsibly as a pathway towards effective citizenship. To establish the relevance of social studies curriculum content in enhancing responsibility among preschool children, content on neighborhood, my school and health practices were singled out. 
Neighborhood

Studying about neighborhood should develop not only an understanding of different people, work activities and recognizing seniors but also instill competencies that lead to sense of responsibility among preschool children. As noted by Seefeldt, Castle, and Falconer, (2010) social studies curriculum is a tool for inculcating right values of the society among children enabling them to emerge as responsible citizens. In this study under the theme of neighborhood, content on persons living in the neighboring area, work activities in the environment and recognizing seniors in community were flagged out and respondents asked the extent they agree on enhancement of responsibility among preschool learners. Their response was then posted in Table 2 .

Table 2. Response on Neighbourhood

\begin{tabular}{lcccc}
\hline & $\begin{array}{c}\text { Persons Living in } \\
\text { Neighbouring Area }\end{array}$ & $\begin{array}{c}\text { Work Activities } \\
\text { in Environment }\end{array}$ & $\begin{array}{c}\text { Recognizing } \\
\text { Seniors in } \\
\text { Community }\end{array}$ & Average \\
\hline Agreed & $83.7 \%$ & $91.8 \%$ & $92.9 \%$ & $89.5 \%$ \\
Uncertain & $2.0 \%$ & $6.1 \%$ & $5.1 \%$ & $4.4 \%$ \\
Disagree & $14.3 \%$ & $2.0 \%$ & $2.0 \%$ & $6.1 \%$ \\
Total & $100.0 \%$ & $100 \%$ & $100 \%$ & $100 \%$ \\
\hline
\end{tabular}

From Table 2, majority of preschool teachers agreed that social studies curriculum content on neighbourhood is relevant as far as enhancing responsibility is concerned among learners. Specifically, $83.7 \%$ preschool teachers used agreed that teaching persons living in the neighbouring area enhances responsibility as a value among learners. Knowledge of people living within the neighbourhood enables learners to appreciate roles of others as was as their own responsibility within the community. This is in concurrence with Paul, Richard and Linda (2006) assertion that social studies curriculum is designed to inculcate sense of responsibility among learners. On work activities in the environment $91.8 \%$ preschool teachers sampled agreed that it is relevant in enhancing responsibility among learners. By agreeing that teaching work activities within the neighbourhood learners become responsible it is clear that this will enable them to know their societal roles. This confirms Nickerson (2011) assertion that social studies curriculum focuses on development of transferrable values learners need for effective citizenship. Further, $92.9 \%$ of preschool teachers agreed that social studies curriculum content on neighbourhood enables learners to recognise seniors in community. This as noted by Copple and Bredekamp (2009) that preschool social studies curriculum content is crucial in developing learners' sense of belonging to the community and country.

My School 
School should be an appropriate environment in teaching social studies curriculum to enable learners to accept responsibility as productive citizens. In this study content on my school was considered to cover teaching about recognizing those in school, their activities and care for school property. Preschool teachers were asked the extent to which they agree that teaching learners to recognize people in school, activities of people in school and care for school property enhance sense of responsibility. The results posted in Table 3 were preschool teachers' responses.

Table 3. Response on My School

\begin{tabular}{lcccc}
\hline & $\begin{array}{c}\text { Recognize people in } \\
\text { school }\end{array}$ & $\begin{array}{c}\text { Activities of } \\
\text { people in the } \\
\text { school }\end{array}$ & $\begin{array}{c}\text { Care for school } \\
\text { property }\end{array}$ & Average \\
\hline Agreed & $92.9 \%$ & $75.5 \%$ & $78.5 \%$ & $82.3 \%$ \\
Uncertain & $5.1 \%$ & $4.1 \%$ & $0 \%$ & $3.1 \%$ \\
Disagree & $2.0 \%$ & $20.4 \%$ & $21.4 \%$ & $14.6 \%$ \\
Total & $100 \%$ & $100 \%$ & $100 \%$ & $100 \%$ \\
\hline
\end{tabular}

Table 3 indicates that $92.9 \%$ of preschool teachers sampled agreed that teaching learners to recognise people in school enhances sense of responsibility. Recognizing people within the school provides an everyday practice embedded in the stream of social interactions. This is further confirmed by the fact that $75.5 \%$ of preschool teachers agreeing that teaching activities of people in school enhance responsibility as a value among learners. These findings echoes Sigurdardottir and Einarsdottir (2016) argument that preschool teachers emphasizes children's participation and development of social skills at school as critical in making them more responsible. Further the findings revealed that $78.5 \%$ of preschool teachers agreed that teaching learners to take care of school properties enhance responsibility. This affirms assertion by Andy, Harsh and Mirriam (2015) that in teaching about school environment plus activities therein and emphasis on cares of properties nurture learners towards establishing personal values.

Health Practices

The extent to which learners could appreciate their environment and be responsible is dependent on relevance of what is learnt on healthy practices. As noted by Odundo, Ganira and Milimu, (2017), children adapt responsible behavior when exposed to appropriate healthy practices during formative years. As part of social studies curriculum content health practices were singled out in this study and preschool teachers were asked to what extent teaching of hand washing, table etiquette and toileting enhance responsibility among children. The results were then presented in Table 4.

From Table 4 it is indicated that $85.7 \%$ of preschool teachers acknowledged that teaching hand washing enhances responsibility among the learners. As noted by Andy, Harsh and Mirriam (2015) reinforcing hand washing is critical towards establishing responsibility as a personal 
value. In agreement, Balwani, Lee and Lee (2017) indicted that reinforcing acts of hand washing reduces incidences of diarrhea, respiratory infections and school absenteeism among children. In nurturing hand washing as healthy practice, teaching social studies at preschool level should enable learners to be responsible and in turn help reducing the risk of water-related disease both at school and home. Results in Table 4.9 also indicates that $89.8 \%$ teachers agreed that teaching feeding as a healthy practice in social studies enhance responsibility among preschool learners in Nairobi County. Teaching table etiquette helps in nurturing healthy feeding habits in childhood as an important factor in child later health. These findings agrees with Shuttleworth and Marri (2014) proposal that social studies curriculum content should be a powerful tool for instilling sense of responsibility among children at preschool level. Appropriate toileting practices creates the first barrier to water born related disease by helping to reduce transmission through direct and indirect route (Corbett, 2012). Table 4.9 also shows that $90.8 \%$ of preschool teachers agreed that teaching toileting as part of social studies curriculum enhancing sense of responsibility among learners. These findings are in concurrence with Paul et al (2006) assertion that social studies curriculum is designed to enhance the value of responsibility through a program of learning that inculcate societal values among learners.

Table 4. Response on Health Practices

\begin{tabular}{lcccc}
\hline & Hand washing & Table Etiquette & Toileting & Average \\
\hline Agreed & $85.7 \%$ & $89.8 \%$ & $90.8 \%$ & $88.8 \%$ \\
Uncertain & $2.0 \%$ & $0 \%$ & $0 \%$ & $0.7 \%$ \\
Disagree & $12.3 \%$ & $10.2 \%$ & $9.2 \%$ & $10.5 \%$ \\
Total & $100 \%$ & $100 \%$ & $100 \%$ & $100 \%$ \\
\hline
\end{tabular}

\section{Conclusion and Recommendation}

The study established that social studies curriculum content is relevant in enhancing responsibility among preschool children. Social studies curriculum content on neighborhood, my school and health practices were singled out as critical in enhancing responsibility among children. Specifically, $89.50 \%$ of preschool teachers used agreed that content on neighborhood enhances responsibility among learners, $82.30 \%$ agreed on my school and $88.80 \%$ agreed health practices. It is through social studies curriculum content that learners learn direct about varied environments in order to develop appropriate knowledge, skills, attitudes and values vital for survival in society as effective citizens.

\section{Recommendations}

The study recommends that schools should strengthen skills that learners already possess and empower them to practice responsibility on daily basis as good citizens. Further, teachers should plan, design class environment and the social studies instruction in ways that cultivate effective civic practice of responsibility. In order to nurture sense of responsibility values education should be given importance in the teaching learning process. 


\section{References}

Andy, W. Harsh, B., \& Miriam, N. (2015). Evaluation of the effect of hand hygiene reminder signs on the use of antimicrobial hand gel in a clinical skills center. Journal of Infection and Public Health, 8, 425-431.

Balwani, C. M., Lee, P.H., \& Lee.R.1.T. (2017). Hand and Hygiene Intervention Strategies to Reduce Diarrhea and Respiratory Infections among Schoolchildren in Developing Countries: A systematic Review. International Journal of Environmental Research and Public Health, 12, 371.

Bracken, S. S., \& Fischel, J. (2007). Relationships between Social Skills, Behavioral Problems, and Readiness for head start children. NHSA dialogue: A Research to Practice Journal for the Early Intervention Field, 10(2), 109-126

Brown, A.L., Crowley, R.M., \& King, L.J. (2011). Black Civitas: An Examination of Carter Woodson's Contributions to Teaching about Race, Citizenship, and the Black Soldier. Theory and Research in Social Education, 39(2), 277299

Carr, D. (2011). Values, virtues and professional development in education and teaching.International Journal of Educational Research, 50, 171-176.

Catherine, R. C., Alexandra, L. N.,\& Campbell, R. (2012). Factors influencing hand washing behavior in primary schools: Process Evaluation within a randomized controlled trial. Health Education Research, 27(6), 1055-1068.

Charlotta, E. (2014). Pedagogies Constructions of Gender Equality in selected preschools: A qualitative study.Education Inquiry, 5, 4.

Cohen, L., Manion, L., \& Morrison, K. (2011) Research Methods in Education (7th ed.). London: Routledge. See especially Chapter 1 on Paradigms of Social Research.

Colker, L.J. (2013). A Place for Building Your Community.Teaching Young Children, 7(1), $18-19$.

Copple, C.,\& Bredekamp, S. (2009). Developmentally Appropriate Practice in Early Childhood Programs - Serving Children from Birth Through Age 8. Washington, D.C.: National Association for the Education of Young Children.

Cresswell, J. (2008). Educational research: Planning, conducting, and evaluating quantitative and qualitative research. New Jersey: Pearson: Merill Prentice Hall

Cresswell, J. W., \& Plano Clark, V. L. (2011).Designing and Conducting Mixed MethodsResearch (second edition). London: Sage.

Crocco, M. S., \& Marino, M. (2014).Investigating a neighborhood: an activity using the c3 framework.

Field, S.L., Bauml, M., \& Ledbetter, M. (2011). Social Studies Every Day: Powerful Integration with English-Language Arts.Social Studies and the Young Learner, 23(3), 22-25.

Fu, C.-S., \& Li, K.-C. (2010). Learning experiences of male pres-service teachers in Taiwan. New Horizons in Education, 58(20), 34-42. 
Ganira, K.L., \& Odundo, P.A. (2017). Influence of Teachers' Knowledge of Content on Effective use of Inquiry- Based Approach in Teaching Preschool Science in Migori County, Kenya. Donnish Journal of Elementary Educational Research and Reviews, 4(1), 001-007.

Ganira, K.L., Odundo, P.A., \& Mwanda, S. (2015). Influence of Psychological needs on Participation of Children aged 4-6 years with Physical Disability in Early Childhood Education classes in Starehe Division, Nairobi County, Kenya. Journal of Educational Research and Studies, 3(2), 30-40.

Gartrell, D. (2012). Education for a Civil Society: How Guidance Teaches Young Children Democratic Life Skills.Washington, DC: NAEYC.

Hansen, H., Holmes, S., \& Lindemann, D. (2013). Ethnography of health for social change: Impact on public perception and policy. Social Science \& Medicine, 99,116-118.

Haradhan, K.M. (2007). Two Criteria for Good Measuring in Research: Validity and Reliability. Annals of SpiruHaret University, 17(3), 58-82.

Kenya Institute of Curriculum Development. (2017). Curriculum Designs in Pre-Primary, Nairobi: Kenya Institute of Curriculum Development.

Kukk, A. (2010). Meeting the objectives of the curriculum in the transfer from a pre-school institution into school and the first stage at school according to the assessments of teachers. Tallinn University, Dissertation on Social Sciences.

Manning, M, Garvis S, Flemming C, \&Wong, T.W.G. (2017).The relationship between teacher qualification and quality of the early childhood care and learning environment.Campbell Systematic Reviews.

Mezieobi, K. A. (2004).Evaluation of the implementation of the junior secondary school social studies curriculum in Abia State. Unpublished PhD thesis. Delta State University, Abraka, Nigeria.

Nelson, B.G., \& Shikwambi, S.-J.(2010). Men in your preparation program.Young Children, 6(10), 36-40.

Ngure, G. (2014).Dynamics of Gender Disparity among Teachers of Young Children in Thika District.Kenya Journal of Education and Practice, 5(10), 57-65.

Nickerson, R.S. (2011). Developing intelligence through instruction.In R.J. Sternberg, \& S.B. Kaufman (Eds.), The Cambridge handbook of intelligence (pp. 107-129). New York: Cambridge University Press.

Odundo, P. A., \& Ganira, G. K. (2017). Teacher Position in Spurring Value Based Education in Early Learning In Nairobi County, Kenya. Addressing Support for Values in School Environment.Journal of Education and Learning,6(3), 194-203.

Odundo, P. A., Ganira, G.K., \& Milimu, G. S. (2017).Adopting Digital Technology in Teaching and Learning Environment in Early Childhood Classes in Nairobi County, Kenya.Asian Educational Studies, 2(3), 18-28.

Orodho. J.A., Nzabalirwa, W.,Odundo, P.A., Ndirangu, P. W., \& Ndayambaji, I. (2016). Qualitative and Quantitative Research Methods in Education and Social Sciences: A 
Step by Step Guide to Scholarly Excellence. First Edition; Kaneza Publishers \& Enterprises Nairobi, Kenya.

Paul, R., \& Linda, E. (2006). Critical Thinking: The Nature of Critical and Creative Thought. Journal of Developmental Education, 30(2), 34-35.

Quashigah, A. Y., Eshun, I., \& Mensah, M. F. (2013).Influences of the pedagogical content knowledge of graduate social studies teachers on questions they set in Senior High Schools in Ghana. Research on Humanities and Social Sciences, 3(6), 76-86.

Regoniel, P. A. (2015). Conceptual Framework: A step by Step Guide on How to make one. In Simply Educate. Me.

Seefeldt, C., Castle, S., \& Falconer, R. (2010). Social Studies for the Preschool/Primary Child (8th ed.). Englewood Cliffs, NJ: Prentice Hall.

Shuttleworth, J. M., \& Marri, A. R. (2014). Teaching sustainability as a social issue: Learning from dialogue in the social studies classroom. In H. E. Muga, \& K. D. Thomas (Eds.), Cases on pedagogical innovations for sustainable development (pp. 328-347). Hershey, PA: IGI Global.

Sigurdardottir, I.,\& Einarsdottir, J. (2016). An Action Research Study in an Icelandic Preschool: Developing Consensus About Values and Values Education. International Journal of Early Childhood. IJEC.

Vygotsky, L. S. (2005). Psihologiarazvitija t eloveka[Psychology of human development]. Moskva: Smõsl.

Wayne Ross, E., Mathison, S., \& Vinson, K. D. (2013). Social studies education and standards-based education reform in North America: curriculum standardization, high-stakes testing, and resistance. Revista Latin-American de EstudiosEducativos, 1(10), 19-48.

Young, M., \& Lambert, D. (2014).Knowledge and the Curriculum of the Future.London: Bloomsbury.

\section{Copyright Disclaimer}

Copyright reserved by the author(s).

This article is an open-access article distributed under the terms and conditions of the Creative Commons Attribution license (http://creativecommons.org/licenses/by/3.0/). 